\title{
Judicialising history or historicisng law: reflections on Irving v Penguin Books and Lipstadt THERESE O'DONNELL ${ }^{1}$
}

\section{Strathclyde University}

Of all the poisons capable of vitiating a piece of evidence, the most virulent is deception. First of all there is ... forgery.

[then] there are sly alterations...

Marc Bloch, The Historians Craft, pp. 75, 81

\begin{abstract}
$\underline{\text { Abstract }}$
In 2000, David Irving brought a libel action against Professor Deborah Lipstadt and Penguin Books focusing on allegedly defamatory allegations in her book. Denying the Holocaust associating him with the Holocaust revisionist movement. The case concluded in April 2000 with Irving's defeat. By focusing on Irving's methodological technique, the defendants succeeded in establishing that Irving's misrepresentations and falsifications were neither accidental nor careless but ideologically motivated. His character was presented and censured as one which manipulated and distorted in order to facilitate a racist agenda.

Presiding judge, Mr Justice Gray was keen not to pollute the exercise of justice by acting as a quasi-historian, nevertheless Irving sharpened the focus on the relationship between historians and courts. Can history migrate from the amphitheatre to the witness box and re-emerge with its integrity intact? Historians are increasingly called as expert witnesses and this has resulted in huge controversies, intra-bistorian strife and debates on experts' ethics. Thus, despite this article's mooring in a Holocaust context, it raises questions relevant to the much wider context of history and law, and as regards "public history". Law and history will meet continuously during litigation. Judicial and historical understandings of evidence should not be either intuitively or automatically elided and even a Holocaust context should not conquer the quest for a mutually self-aware relationship. Without engaging in endless discussions concerning the nature of knowledge and the philosophy of history, judges require standards for assessing the weight of historical evidence to ensure "intellectual due process" and that, evidentially at least, legal conclusions are sound. How can historians best facilitate the legal process and how can lanyers avoid mistranslating historical work? A legally created standard (such as Mr Justice Gray attempted) for expert evidence appears attractive. Admissibility or reliability tests are options and open up issues such as bar-appointed experts and expert ethical codes. Ultimately, the quest is not to crowbar unwilling historians into roles as mere judicial handmaidens, but instead to recognise wider societal contributions of historians and to give due credit to the "reasonable bistorian".

When historians appear as expert witnesses, they are not "doing history", they are communicating historical expertise in another forum. Such cross-pollinating communication or "public bistory" is a process of translation. Undoubtedly, law is the dominant discipline in court and bistory is being instrumentalised. However, with due care, such interactions need not distort complex historical studies or restrict future historical research. Disciplinary faithfulness can be preserved by legal reliance on historical guild-standards. In this way, standards regarding intellectual rigour and methodological integrity are safeguarded and notions that there is one history for historians and another/lesser one for courts are avoided.
\end{abstract}

1 Irving v Penguin Books Ltd and Lipstadt, No 1996-I-113, [2000] All ER (D) 5232000 WL 362478 (QB 11 April 2000). The Court of Appeal (2001 WL 825074) refused leave to appeal. 


\section{Introduction}

$\mathrm{D}_{1}$ avid Irving's High Court libel case against Professor Deborah Lipstadt and Penguin Books concluded in April 2000. Irving's action focused on allegedly defamatory allegations in Lipstadt's book Denying the Holocaust ${ }^{2}$ associating him with the Holocaust revisionist movement. These included that, as an ultra-nationalist with Hitler's self-portrait over his desk, Irving conceived of himself as carrying on Hitler's legacy, and that Irving was scheduled to speak at a 1992 Swedish anti-Zionist conference alongside representatives from anti-Semitic and anti-Israel organisations. ${ }^{3}$ Finally, Lipstadt maintained that Holocaust deniers misstate, misquote, falsify statistics and falsely attribute conclusions to reliable sources. Irving was thus distinguishable from other Holocaust denial cases which tended to focus on the criminality of publications or utterances. ${ }^{4}$ Ultimately, the defence of justification succeeded overall against Irving, ${ }^{5}$ simultaneously demolishing his status as a historian.

Just as the Nuremberg trials' narrative is simplified as the unfolding of a conspiracy tale (rather than an examination of each defendant's conduct), ${ }^{6}$ so Irving has often been reduced to a straightforward reaffirmation of the Holocaust's existence and a condemnation of those disputing it as racists. ${ }^{7}$ However, Irving entertains wider possibilities for influencing and refining the interactions between historians and lawyers in contentious legal proceedings. It poses questions regarding the management of this very particular form of "public history"8 whereby historians move beyond intra-disciplinary discussions. Renouncing "the privacy and protection of their classrooms and research institutes . . . [historians] . . become public figures". ${ }^{9}$ This article addresses a variety of issues including complexities in defining Holocaust denial and the distinctions between legitimate criticism and prejudiced vilification. Mr Justice Gray (sitting alone) emphasised his avoidance of polluting justice with quasi-historical analysis. ${ }^{10}$ Nevertheless, historiographical methodologies and skills were key issues in play. Mr Justice Gray's reliance on documentary evidence and repeated references to expert historical witnesses resulted in his moulding criteria with potential to clarify judicial roles regarding the admission and evaluation of historical evidence. Irving revealed the complexities of the law-history relationship, notably in the differing understandings of evidence. The justification defence demanded analysis not of whether the Holocaust happened but whether Irving's research was driven by his particular (racist and anti-Semitic) ideology. Dismissing his alleged links with other deniers as guilt by association, ${ }^{11}$ Irving denied membership of Holocaust denial or

2 D Lipstadt, Denying the Holocaust (London: Penguin 1994).

3 Ibid. pp. 14, 111, 161, 179, 181, 213, 221.

4 This article does not deal with the detail of Holocaust denial laws or trials.

5 Judgment 13.165-8, A Julius, "London and libel" (2000) 11(Fall) Experience 8, p. 13.

6 T O'Donnell, "Executioners, bystanders and victims: collective guilt, the legacy of denazification and the birth of 20th century transitional justice" (2005) 25(4) Legal Studies 627, referring to D Cohen, "Beyond Nuremberg: individual responsibility for war crimes" in R C Post and C Hesse (eds), Human Rights in Political Transitions (New York: Zone Press 1999).

7 See the comments of Rabbi Dr Jonathan Romain (Reform Synagogues of Great Britain) and Dror Zeigerman (UK Israeli ambassador), V Dodd "Irving consigned to history as a racist liar", The Guardian, 12 April 2000.

8 P K Leffler and J Brent, Public and Academic History: A philosophy and a paradigm (Malabar FL: Krieger 1990) and J B Gardner and P S LaPaglia, Public History: Essays from the field ((Malabar FL: Krieger 1999), P Novick, That Noble Dream (Cambridge: CUP 1999), pp. 512-21.

9 C Fink, "A new historian?” (2005) 14 Contemporary European History 135, p. 147.

10 C Ginzburg, The Judge and the Historian (New York: Verso 1999) 119. See also A I Davidson, "Carlo Ginzburg and the renewal of historiography" in J Chandler, A Davidson and H Harootunian (eds), Questions of Evidence (Chicago: Chicago UP 1994), p. 304.

11 Judgment 8.11. 
"revisionist" / "negationist" movements (despite having acted as an expert witness in Ernest Zundel's Canadian prosecution for the publication of false news harmful to the public interest). ${ }^{12}$ Irving proclaimed historians' rights to dissent from mainstream views ${ }^{13}$ on the Holocaust, thereby spurring examinations of "objective" and "relativist" (or "perspectival") historical schools. This article will focus upon the empirical character of litigation rather than normative understandings of historical knowledge. It will defend a legal standard benchmarking reliability of expert evidence, in this case, that of the "reasonable historian". Such a standard will avoid an imperial project by law into the realm of history by instead encouraging a partnership between law and history in an effort to enhance the administration of justice. Clio (the muse of history) should be able to migrate from the amphitheatre to the witness box to aid Portia in her endeavours. ${ }^{14}$

\section{Holocaust denial}

\section{Definitions of Holocaust denial}

Without a specific UK law, defining Holocaust denial/negationism is difficult. Broadly, denial definitions veer along a spectrum. At one end, negationism only occurs where the specific figure of $6 \mathrm{~m}$ dead and the existence of concentration camps are denied. At the other end, denial is considered wide enough to embrace: any questioning of a survivor's testimony; denunciation of Jewish collaborators' roles; suggestions of German suffering during the Dresden bombing; or statements that any state except Nazi Germany committed Second World War crimes. ${ }^{15}$ Wide definitions might exclude legitimate intellectual discourse $\mathrm{e}^{16}$ and although negationism is distinguishable from legitimate historical debate by virtue of its in-built anti-Semitism, ${ }^{17}$ divining the borderline between the two can be difficult. For some, denying the Holocaust's uniqueness constitutes denial. Lipstadt herself considers comparisons with Armenian, Cambodian or Stalinist massacres to be invalid, believing them to be problematically designed to assist Germans in embracing their past as being indistinguishable from those of countless others. ${ }^{18}$ While accepting that such comparative historians are not crypto-deniers, she considers the results of their work to correspond: the blurring of boundaries between fact and fiction, and between persecuted and persecutor. ${ }^{19}$ However, many contemporary oppressors take behavioural cues from Nazism. Rather than diminishing the Holocaust, descriptions of "Nazi-style" practices may instead emphasise the horror of subsequent events, for example ethnic cleansing, detention centres, ghettoes and camps in Yugoslavia. ${ }^{20}$

12 R v Zundel, Zundel v Canada (1993) 95 DLR (4th) 202; [1992] 75 CCC (3d) 449, G Weimann and C Winn, Hate on Trial (Oakville: Mosaic Press 1986). Zundel had published a pamphlet entitled "Did six million really die?". Tried twice, his conviction was overturned twice.

13 Judgment 8.13.

14 O Dumoulin, Le role social de l'historien: De la chaire au prétoire (Paris: Albin Michel 2003); Fink, "New historian", n. 9 above, p. 137. See the approach of the historians Lucien Febvre and Marc Bloch who encouraged interdisciplinarity in considering the structures which explain events and the social functions of ideas and institutions. See M Bloch, The Historian's Craft, P Putnam (trans.) (Manchester: Manchester UP 2010), pp. 18, 155.

15 Lipstadt, Denying, n. 2 above, pp. 6, 12, 22, 89-90.

16 Judgment 13.104.

17 J Cooper and A M Williams, "Hate speech, holocaust denial and international human rights law" (1999) EHRLR 593, p. 595.

18 Lipstadt, Denying, n. 2 above, ch. 11.

19 Ibid. pp. 212-15.

20 Application of the Convention on the Prevention and Punishment of the Crime of Genocide http://www.icj-cij.org. 
Professor Richard Evans acted as an expert witness in Irving. Drawing on his and others' expertise $^{21}$ in historiographical practice, he concluded that Holocaust denial encompassed certain allegations:

a) Jews killed by the Nazis amounted to only a few hundred thousand, being similar to or less than, numbers of German civilians killed in Allied bombing raids;

b) gas chambers were not used to kill large numbers of Jews at any time;

c) neither Hitler nor the Nazi leadership in general had an extermination programme regarding Europe's Jews, wishing simply to deport them to Eastern Europe;

d) the Holocaust was an Allied wartime propaganda-myth, since sustained and utilised by Jews to gain political and financial support for Israel or for themselves;

e) any evidence for Nazi wartime Jewish mass murder by gassing and other means was fabricated post-war. ${ }^{22}$

Irving traversed into Holocaust denial by numerically equating camp deaths with deaths resulting from Allied bombing raids, claiming they amounted to thousands not millions. He disputed the systematic nature of concentration camp exterminations, ${ }^{23}$ and Hitler's sanctioning of such killings. ${ }^{24} \mathrm{He}$ frequently questioned the existence of the Auschwitz gas chambers, once asking a Holocaust victim how much money she had made from her tattoo. 25

\section{HOLOCAUST DENIAL'S ACADEMIC PRETENSIONS}

[Holocaust denial's] perfidiousness lies precisely in its seeming to be precisely what it is not, an attempt to write and think through history. ${ }^{26}$

By imitating the mainstream academy, deniers seek acknowledgment as purveyors of an alternative historical truth. Relying on each other's work, they organise journals, conferences and institutes to exchange views and disseminate publications. Robert Faurisson (prosecuted for revisionism under French law in 1991) ${ }^{27}$ was a former university lecturer involved in the Institute of Historical Review which ran conferences and published an associated journal. Such academic mimicry attempts clear distinctions between serious historical work and obviously racist violence. However, as creators of a virtual history geared at an event's eradication from history, deniers have been denounced as "paper Eichmanns". ${ }^{28}$ If the Final Solution anticipated both extermination and the "erasure of any memory of the killings" then clear conceptual linkages between denier-trials and perpetrator-trials ${ }^{29}$ emerge. Distinctions between legitimate historical research and negationists' work lie not in fallibility tests (historical truths can always be revisited) but in

21 Evans was the modern German history professor at Cambridge University, and drew on Michael Marrus, Martin Gilbert and Landau. See also P Vidal-Naquet, Assassins of Memory, J Mehlman (trans.) (New York: Columbia UP 1992), pp. 18-19.

22 R Evans, Lying About Hitler (New York: Basic Books 2001), p. 110.

23 Judgment 8.9, 8.15-8.17

24 Discussed below.

25 Judgment 13.95, 8.17.

26 Vidal-Naquet, Assassins, n. 21 above, p. 111.

27 E.g. Faurisson v France Comm No 550/1993, UN doc. CCPR/C/58/D/550/1993, (1997) 18 HRLJ 40. The 1990 Gayssot Act made it an offence to contest publicly (Nuremberg-defined) crimes against humanity.

28 Vidal-Naquet, Assassins, n. 21 above, p. 98, 24.

29 L Douglas, The Memory of Judgment (New Haven: Yale UP 2001), pp. 215. 
deniers' willingness to manipulate, mistranslate, use discredited testimony, falsify statistics or apply double standards. ${ }^{30}$ Indeed, revisionists' apparently scholarly tactics even mimic the outer extremities of law's adversarialism. ${ }^{31}$ As such, several established historians argue that law never overlaps with history, only quasi-history, ideological history or law-office history ${ }^{32}$ (referred to below).

Irving shunned academic communities, criticising "inter-historian incest". 33 Relying on primary sources, he prided himself on recovering original facts and documents, obsessively and cumbersomely footnoting and referencing. However, for both historians and lawyers, direct participant evidence is not always the best evidence. Such memoirs might be sentimental or, with one eye on posterity, self-interested. Irving's "meticulous" sourcing could be recast as fetishistic, journalistic or even illusionist-like. Fact isolation is a hallmark negationist approach, whereas mainstream historians draw their conclusions from the convergence of varyingly sourced evidence. Irving's approach evidenced a pathological desire for historical proximity, to "touch" history rather than expertly evaluate it emotional rather than scientific. From a liberal perspective, universities might appear optimal venues for exposing Irving's views. However, the Oxford University Union was pressured into withdrawing a 2001 offer of participation and the UK National Union of Students adopted a "no platform" policy towards racist speakers of which Irving fell foul. ${ }^{34}$ Irving's attempts to speak at Trinity College Dublin and University College Cork were met by student protests. No speaking invitations emanated from university history departments, highlighting the mainstream academy's contempt for Irving's work.

Having alluded to the general definitional difficulties surrounding Holocaust denial and the community's modus operandi, the article will now move to an examination of the case.

\section{The evidence and purpose of Irving v Lipstadt}

\section{OVERVIEW: WRITING THE WRONGS OF HISTORY OR SPIN TIME FOR HITLER?}

Irving's success depended on his establishment that, as a matter of ordinary probability, the disputed material contained passages which would cause ordinary, reasonable, readers to think worse of him. A prima facie case was established as the relevant book passages bore defamatory meanings. First, that Irving was an apologist for and partisan of Hitler who distorted evidence to exonerate Hitler and portray him as sympathetic towards Jews. Secondly, Irving was a dangerous spokesman for Holocaust denial by denying that the Nazis had embarked upon a deliberate planned extermination of Jews and by maintaining that Auschwitz's gas chambers were a Jewish deception. Thirdly, in denying the Holocaust's occurrence, Irving had misstated evidence, misquoted sources, falsified statistics, misconstrued information and bent historical evidence so that it conformed to his neofascist political agenda and ideological beliefs. Fourthly, Irving had allied himself with representatives of a variety of extremist and anti-Semitic groups and individuals. Finally, Irving was discredited as an historian. Lipstadt was simply required to prove that the allegations were substantially true and that Irving's misrepresentation and falsification were deliberate, motivated by his ideological beliefs or prejudices. Mr Justice Gray acknowledged

30 Evans, Lying, n. 22 above, pp. 33 and 239, discussing Lipstadt's accusations and Tony Judt's thoughts in "Wahrheit oder Integrität", Süddeutsche Zeitung, 14 April 2000.

31 Douglas, The Memory, n. 29 above, p. 235.

32 J D Martin "Historians at the gate: accommodating expert historical testimony in federal courts" (2003) 78 NYULR 1518, pp. 1525-6.

33 D Irving, Hitler's War (London: Hodder \& Stoughton 1977).

34 See also the Education Act 1986 No 2. 
that despite the standard of proof remaining the civil standard, serious allegations demand stronger evidence. This weighted standard captured the peculiar character of the case. Ultimately, despite the prima facie presumption against Lipstadt's allegations, her defence succeeded overall.

The defendants outlined 19 instances of Irving's distortion of the evidence. Only particularly significant instances chronicling events both before and during the Second World War, the genesis of the Final Solution and Irving's portrayal of Hitler as sympathetic to the Jews are highlighted below.

\section{THE EVIDENCE}

\section{Hitler: the responsible authority figure}

Hitler went on trial in 1924 for the 1923 Munich Beer Hall putsch. ${ }^{35}$ In Hitler's War (1991 edition), Irving claimed that Hitler disciplined a Nazi squad for looting a Jewish delicatessen during the putsch. Despite later changing such castigation to a mere reprimand of only one individual, it clearly implied Hitler's abhorrence of anti-Semitic acts. Evidence came from a police sergeant's statement, but neither he, nor the date of his statement, was footnoted an absence Irving blamed on the publisher's desire for editing. Professor Evans tracked down the witness. Hoffman was a Nazi Party member, the admonition was before the putsch and, in fact, evidence existed that Hitler had ordered a raid on a Jewish printing house. Hitler was not trying to maintain order. Irving claimed no knowledge that Hoffmann was a longstanding Nazi, despite its obviousness on the testimony's face. Claiming not to have read the verbatim transcription of trial evidence, Irving had not "paid attention" to Hoffmann's statement regarding his background and maintained that readers could discern Hoffmann's lack of objectivity. In fact, Irving embroidered evidence of Hitler, presenting him as behaving responsibly in disciplining a recalcitrant soldier. ${ }^{36}$ In his book Goering, Irving misleadingly recast the consequent violent theft of $14.5 \mathrm{bn}$ marks as a "requisition" of funds.

During Kristallnacht ${ }^{37}$ 1938, 76 synagogues were destroyed, a further 191 set on fire, 7500 Jewish shops and businesses were destroyed and widespread looting occurred. Twenty thousand Jews were arrested and sent to concentration camps. Irving placed blame squarely on Goebbels, alleging that Hitler neither knew about nor approved the actions and, upon late discovery on 9 November, was angry and tried to stop events. ${ }^{38}$ The defence maintained that Irving's position was only sustainable by mistranslating Goebbels' diary entry which actually recorded a Hitler order to "withdraw" the police, i.e. the complete removal of the police from the violence. Irving's Goebbels book translated it as "hold back". Hitler's desire for the Jews to "feel the people's fury" was recast in Irving's Goebbels as them merely being "given a taste of the public anger".

The defendants further alleged that Irving distorted Hitler's role by omitting reference to a telegram sent at $11.55 \mathrm{pm}$ on 9 November 1938 by Muller, the head of Security Police, to officers. This warned of imminent anti-Jewish demonstrations, ordered no interruptions and ostensibly showed Muller's acting on the highest orders, reflecting precisely Hitler's earlier order. Evans criticised Irving's use of telexes as misleadingly portraying Hitler as trying to use the police to halt events when proper interpretations indicated police non-intervention unless non-Jewish properties were threatened. ${ }^{39}$ Irving had introduced evidence of Wilhelm

35 Judgment 5.17-5.28.

36 Judgment 13.12.

37 Judgment 5.37-5.72.

38 However, Kristallnacht operations were reported in the Nazi press early on 9 November 1938.

39 Judgment 5.59. 
Bruckner, Hitler's former chief personal adjutant, testifying to Hitler's being "livid" on discovering the facts at $1 \mathrm{am}$ on 10 November 1938, but he could not produce any documentary evidence. ${ }^{40} \mathrm{Mr}$ Justice Gray considered that re-directing sole blame onto Goebbels stood at odds with documentary evidence. Scant attention was paid to evidence implicating Hitler, instead a misleading and partial account of Goebbels' diary was offered. Evidence from Hitler's adjutants should have been treated with considerable scepticism and rejected where it conflicted with the evidence of contemporaneous documents.

\section{Hitler's views on the Jewish question ${ }^{41}$}

Although Hitler may not always have spoken in actually genocidal terms, by 1941 his pronouncements on the Jewish question were sinister, especially seen in the context of: Hitler's history of anti-Semitism; Nazism's ideology of racial purity; pre-war attacks on Jews/Jewish property; policies of Jewish deportations; and (Hitler-approved) systematic shootings of Jews in the East. Despite Irving's evidence of Hitler's sympathetic and protective attitude to the Jewish question, post-1941, the few documents emerging were unequivocal. Interpretations suggesting deportation (rather than extermination) were perverse. Irving had seriously misrepresented Hitler's views by misinterpreting, mistranslating and selectively using documents, notably the Schlegelberger memo ${ }^{42}$ which Irving maintained was from spring 1942 and demonstrated Hitler's wish to postpone the Jewish question until post-war. However, Irving could not explain Hitler's supposed decision in March 1942 to halt a programme already underway on a massive scale for at least six months. Professor Evans' evidence that the note solely referred to mischlinge (half-Jews) was more convincing. ${ }^{43}$

The scale and systematic nature of Einsatzgruppen shootings of Jews, the extent of Jewish gassings in certain camps (excluding Auschwitz) and Hitler's knowledge and complicity in this particular gassing programme, evidenced his persistent anti-Semitism to any dispassionate historian. ${ }^{44}$ When Irving told audiences that Einsatzgruppen killings were arbitrary, unauthorised and individually executed, he misrepresented the historical evidence. Irving's eventual acceptance that Chelmo, Treblinka and Sobibor were Nazi killing centres was grudging and disingenuous. ${ }^{45} \mathrm{Mr}$ Justice Gray was unconvinced of Hitler's being "kept in ignorance" of genocidal gas chambers at Reinhard camps. ${ }^{46}$ Himmler's daily calendar recorded regular meetings between himself and Hitler discussing the Jewish question while Himmler was supervising the establishment and operation of gas chambers in these camps. Further, the January 1942 Wannsee protocol recorded Heydrich's opening remarks that he spoke with Hitler's authority. Such evidence was as available to Irving as it was to two defence expert historians, Christopher Browning and Peter Longerich (the latter testifying to Hitler's role in the formulation and execution of Nazi anti-Semitic policies). ${ }^{47}$ These witnesses gave convincing testimony that the evidence made it inconceivable that Hitler did not know of and authorise mass gassing of Jews. ${ }^{48}$

40 In fairness, Irving had donated Bruckner's papers to the Institute of History in Munich to which he no longer had access.

41 Judgment 5.123-5.150, 13.26-13.31.

42 An official in the Reich Ministry of Justice. See Judgment 5.151-169.

43 Judgment 13.35-13.36.

44 Judgment 13.55-13.67.

45 Claiming to do so only to quicken the trial's progress, Judgment 13.63.

46 Which Irving argued were planned and implemented by Heydrich and overseen by Himmler, Judgment 13.64-7.

47 He later published, The Unwritten Order (Stroud: History Press 2001).

48 Judgment 13.67 and 6.105 


\section{Auschwitz $^{49}$}

Irving eventually acknowledged that at least one gas chamber existed at Auschwitz (for fumigation of clothing) and that gassing of Jews took place there "on some scale". The question therefore centred on numbers and on causes. Such is Auschwitz's emblematic power in Holocaust history that it is impossible for preconceptions not to intrude. Mr Justice Gray was extremely conscious about the dangers of remembering representations of the real while overlooking the real evidence itself. The danger of learning history from dramas, and even more confusingly, docudramas, ${ }^{50}$ is prevalent in the post-modern world. Reconstructions or images of events seem more real than the events themselves - la société du spectacle. ${ }^{51}$ As one defence expert, Robert Jan van Pelt noted, Auschwitz has become detached from its own evidence. van Pelt is an architectural historian who testified to the existence of Auschwitz's gassing equipment and even he felt compelled to engage in a reflective epistemological analysis regarding his own knowledge of Auschwitz. ${ }^{52}$

Irving doubted the authenticity of a letter dealing with the incineration capacity of ovens, and photographic evidence. He also cast doubt on accounts given by camp survivors and camp officials: that some witnesses invented some/all of the experiences described; accounts were cross-pollinated; that repeated and embellished testimony led to construction of a corpus of false testimony; and that some witnesses were clearly wrong or had exaggerated. However, eye-witness evidence in one case was so clear and detailed that no objective historian would dismiss it without powerful reasons. Documents did exist for which it was hard to find an innocent explanation, including a letter from the Chief of Central Construction at Auschwitz regarding ovens' capacity. Converging evidence indicated that large numbers of Jews were killed at Auschwitz. Exceedingly powerful reasons were required to reject that conclusion. Irving partially relied on the 1988 Leuchter Report which employed chemical analysis of samples taken from brickwork and plaster at Auschwitz to argue that the concentrations of cyanide found were insufficient to kill humans and that such buildings were fumigation, not extermination, facilities. The report was produced by Fred Leuchter during one of Ernst Zundel's previously mentioned Canadian trials. Its foreword was written by the aforementioned convicted denier Robert Faurisson. Given the Leuchter Report's general discrediting, 53 any objective historian would have doubted it. An undressing room (requested by the camp doctor in January 1943) would have been unnecessary for a corpsefumigation chamber. A spy-hole in a gas-tight door was equally inexplicable. Crematorium 2 was not an air raid shelter. At best, Irving's non-genocidal position could only be a conceptual, not a historical possibility. Auschwitz intertwined with all of the other contemporaneous history, including Einsatzgruppen behaviour, deportations to the East, initial experiments with Zyklon B, the expansion of concentration camps, and so on. Proving isolated facts meant nothing, inter-connectedness was crucial. As van Pelt noted, challenging Auschwitz meant challenging "not only the history of the Holocaust but much of the history of the war itself". 54 Leuchter and Irving were stuck in the wider consensus.

49 Judgment 13.68-13.91.

50 Ginzburg, The Judge, n. 10 above, Evans, Lying, n. 22 above, pp. 323-4.

51 G Debord, The Society of the Spectacle (Sussex: Soul Bay 2009).

52 R J van Pelt, The Case for Auschwitz (Bloomington and Indianapolis: Indiana UP 2002), pp. 103-4.

53 S Shapiro (ed.), Demolishing Holocaust Denial: The end of the “Leuchter Report” (New York: St Martin's Press 1990).

54 van Pelt, The Case, n. 52 above, p. 104. 


\section{Dresden $^{55}$}

Irving estimated approximately 100,000 Jewish deaths at most in Auschwitz and relied on a particular order (Tagesbefeb) TB47 which estimated Allied-bombed Dresden dead at 200,000 to 250,000 . Consequently, the numbers grotesquely "neutralised" each other. The widely accepted Dresden death figure is approximately 30,000. ${ }^{56}$ Having previously acknowledged in 1963 that TB47 was a forgery, Irving subsequently changed his mind. Yet its use surely demanded extreme caution especially in the light of increasing documentation doubting its reliability. Corroborating evidence for the higher figure was never produced. Irving's evidence was second-hand, unverified and lacking any evidential basis.

\section{IRVING'S IDEOLOGICAL POSITION}

Ostensibly, Irving's racism, anti-Semitism or associations seem irrelevant, implying judgment of character rather than conduct. However, the defence needed to establish that Irving's misrepresentations and falsifications were neither accidental nor careless but ideologically motivated. ${ }^{57}$ Irving's anti-Semitism (defined by the defendants as "theory, action or practice directed against the Jews") 58 was established via numerous of his diary entries, speeches and the "Action Report" available on his website. Evidence regarding Irving's alleged association with German right-wing and neo-Nazi groups/individuals was given by Dr Hajo Funke, Professor of Political Science at Berlin Free University. Suggesting that anti-Semitism sprang from Jewish conduct and attitude, Irving referred to Holocaust compensation claims and Jewish financiers' dishonesty. ${ }^{59}$ Claims that he was merely explaining anti-Semitism were unsustainable given his descent into prejudiced vilification, ${ }^{60}$ including likening the British Board of Jewish Deputies to cockroaches. ${ }^{61}$ Irving also associated with extreme right-wing political groupings, including a revisionist organisation (the Institute of Historical Review) and a neo-Nazi, anti-Semitic organisation (the National Alliance), which indicated compatible ideologies. ${ }^{62}$

\section{CONCLUSION ON IRVING THE HISTORIAN}

All of Irving's "mistakes" converged to exonerate Hitler, none had the opposite effect. The level of perversity and egregiousness which some of them displayed excluded Irving's innocent explanations. ${ }^{63}$ For example, he claimed the exclusion of details of a Hitler order concerning the shooting of Berlin Jews in Riga resulted from an effort to ameliorate reader boredom. He dismissed documents which contested his thesis, did not conform to his ideological agenda, or were inconvenient. Irving employed double standards to sources accepting TB47 yet criticising Anne Frank's diaries which had been rigorously forensically tested. Similarly, in relation to eye-witnesses, testimonies of survivors and camp officials were doubted yet those of Hitler's adjutants were accepted. Irving's manipulation of the

55 Judgment 11.1-11.55 and 13.116-13.126. See J Vergés' tactics in Barbie regarding French crimes in Algeria and N Wood, "Crimes or Misdemeanours? Memory on trial in contemporary France" (1994) 5 French Cultural Studies 1, p. 9.

56 Judgment $11.19,11.40$.

57 Judgment 9.1.

58 Judgment 9.4 .

59 Judgment 9.5, 9.6 (including Irving's recitation of a derogatory rhyme with his infant daughter on seeing "halfbreed children”), 9.10, 13.101.

60 Judgment 13.103-13.105.

61 Judgment 9.5(xxiv).

62 Judgment 13.109-13.115.

63 Judgment 13.142. 
evidence together with his denials of the Holocaust, his racism, his anti-Semitism and his association with right-wing extremists evidenced a pattern in his activities and attitudes. ${ }^{64}$

\section{THE HISTORIOGRAPHICAL APPROACH}

Despite the European Commission of Human Rights having taken notice of the Holocaust as a historical fact involving "overwhelming evidence of all kind", 65 concerns persist over courts operating as arbiters of history. Mr Justice Gray was clear that "it is not for me to form, still less express, a judgment about what happened. That is a task for historians."66 After all, the Holocaust's validity as an event did not depend upon it being judicially established. History is not written in courts and Irving's outcome could not change the events of $1933-45.67$

However, in Irving, law and history did interact by being concerned with interpretations of the past and legally judging them against acceptable historical standards, as testified to by expert historians. By focusing on methodology and historiography, Irving involved empirical analysis of Irving's method 68 in judging whether a defence of justification was made out. Criminal "perpetrator trials" look at the contrasting evidence regarding an event's occurrence and apportion responsibility accordingly. Instead, Irving concerned the representation of events. As "a trial about the Holocaust in history", instead of a Holocaust trial, ${ }^{69}$ it was less about the life of Auschwitz than the afterlife of Auschwitz. ${ }^{70}$ Is this distinction technically attractive but disingenuous? Arguably, adopting the historiographical approach (legal analysis of method) as opposed to the "historical" one (i.e. proving the Holocaust did happen) allowed an arrival at the same conclusion as the latter approach, minus the positive burden of proving the Holocaust. ${ }^{71}$ However, differences underlie the motivation of each approach. In Irving, the defence expert reports went a long way to showing the evidence of past events but, more importantly, they highlighted evidence which objective, fair-minded commentators were required to take into account, illustrating Irving's shortcomings and thereby laying the ground for a successful defence.

\section{EXPERT WITNESSES $V$ SURVIVOR WITNESSES}

Notwithstanding the acknowledged power of first-person testimony, ${ }^{72}$ its use is limited in trials involving the Second World War. Even the contemporaneous Nuremberg proceedings (perhaps highlighting law's desire for systematic objectivity) preferred documentary "disinterestedness and unquestioned authenticity". ${ }^{73}$ While first-hand testimony is an

64 Judgment 13.162-13.163.

65 European Commission of Human Rights case of Xv FRG 29 DR 194 (1982). In the first Canadian Zundel case, Judge Locke refused judicial notice and was supported in the Ontario Court of Appeals despite it overturning the conviction. In the second Zundel case, general judicial notice of the Holocaust was taken, justified as being within judicial discretion, Douglas, The Memory, n. 29 above, pp. 246-7.

66 Judgment 1.3.

67 S Moss, "History's verdict on Holocaust upheld", The Guardian, 12 April 2000.

68 R Evans, "History, memory and the law: the historian as expert witness" (2002) 41 History and Theory 326, p. 341.

69 D D Guttenplan, The Holocaust on Trial (London: Granta 2001), p. 96.

70 D Pendas, “The case for Auschwitz”, book review (2003) 17(2) Holocaust \& Genocide Studies 375, p. 377.

71 Julius, "London and libel", n. 5 above, p. 13.

72 See Claude Lanzmann's landmark documentary Shoah. See S Felman, "Film as witness: Claude Lanzmann's Shoab" in G Hartman (ed.), Holocaust Remembrance: The shapes of memory (Cambridge MA: Blackwell 1994), p. 90, and "A ghost in the house of justice: death and the language of the law" (2001) 13 Yale JL \& Human 241.

73 R H Jackson, The Nurnberg Case (New York: Alfred A Knopf 1947), p. viii; P Novick, The Holocaust in American Life (Boston/New York: Houghton Mifflin 1999). 
historical source, in Irving what was needed was expertise involving empirical knowledge of historiography. ${ }^{74}$ For example, first-hand, autobiographical evidence could not testify regarding evidence of an extermination programme's overall scale. Using survivor witnesses would have ended up debating the Holocaust's existence, not Irving's method. Brutal crossexamination ${ }^{75}$ overstating minor inconsistencies would have transferred attention away from Irving's method ${ }^{76}$ as had been seen in the first Zundel case. ${ }^{77}$ Absenting the "voice of memory" imposed greater pressure "on the words of history". ${ }^{78}$ Thus begins the analysis of the role of expert historians in court.

\section{The relationship between history and courts}

\section{LAW AND HISTORY: SOULMATES OR STRANGERS?}

Both law and history employ the "evidential paradigm". 79 Historians authenticate documentation in cases, ${ }^{80}$ utilise court records in their research, file amicus curiae briefs. ${ }^{81}$ and benefit from the emergence of new historical information during legal proceedings which fuels ongoing historical debates. ${ }^{82}$ Lawsuits often lend urgency, prompting litigation targets to open archives, thus aiding the historian's enterprise. David Rosner explicitly attributes his book Deceit and Denial: The deadly politics of industrial pollution to litigation which made possible his access to internal memos and minutes of meetings involving company representatives. The book in turn facilitated further legal actions. ${ }^{83}$ Indeed, it is often law which determines historical access to classified archives, facilitating history's eternal reexamination of the past. Companies have also commissioned official histories which have been crucial as regards litigation for wartime wrongs. Nevertheless, antagonism pervades much of history's interaction with law. A key question is therefore whether the ostensibly strained, combative relationship between lawyers and historians (as regards the importance and use of expert evidence) be recast from a zero-sum, winners/losers paradigm, into a working partnership in the administration of justice? There is a need to move from the sense that law seeks smoking guns or indisputable "fingerprints", 84 that law's desire for legal finality eschews any nuance and contradiction and somehow tarnishes the historical process

74 Evans, "History", n. 68 above, pp. 332, 339. See also H Rousso, The Haunting Past, R Schoolcraft (trans.) (Philadelphia: Pennsylvania UP 2002), p. 79.

75 Eichmann illustrated the traumas of giving evidence even in supportive surroundings, $\mathrm{H}$ Arendt, Eichmann in Jerusalem (New York: Viking Press 1987), ch. 24.

76 Evans, Lying, n. 22 above, pp. 263-4. See also Libson's and Julius' concerns referred to in Guttenplan, The Holocaust, n. 69 above, pp. 95-6.

77 An Auschwitz escapee Rudolf Vrba was challenged over his calculations of a cremation pit's dimensions. Such witnesses were notably absent from the prosecution case in the second set of proceedings, Douglas, The Memory, n. 29 above, pp. 239, 248.

78 Ibid. p. 246.

79 C Ginzburg, "Clues: roots of an evidential paradigm" in J and A C Tedeschi (trans.), Clues, Myths, and the Historical Method (Baltimore: Johns Hopkins UP 1992), p. 96.

80 See Raul Hilberg's evidence in US v Stelmokas 100 F3d 302, 307 (3d Cir 1996) mentioned in M D Goodman, "Slipping through the gate: trusting Daubert and trial procedures to reveal the 'Pseudo-historian' expert witness and to enable the reliable historian expert witness - troubling lessons from Holocaust related trials" (2008) 60 Baylor LR 824, pp. 834-5.

81 Lawrence v Texas 539 US 558 (2003) concerning Texan sodomy laws, Planned Parenthood of Se. Pa. v Casey 505 US 833 (1992) regarding abortion waiting periods and parental consent.

82 Regarding inter-historian rivalries post-Romer v Evans 517 US 620 (1996), see Goodman, "Slipping through", n. 80 above, fn. 37.

83 D Rosner, "Trials and tribulations: what happens when historians enter the courtroom" (2009) 72 Law \& Contemporary Problems 137, pp. 149-51.

84 Moss, "History's verdict", n. 67 above. 
of eternal re-examination, and that law is history's particular nemesis in the way it is not for other disciplines.

It is important to note that clear divisions exist among historians as to how they envisage their relationships with law. One school pursues a separatist line, notably Henry Rousso who refused to testify in various French war crimes trials in the $1990 \mathrm{~s} .{ }^{85}$ This was borne of concerns that history appeared as a tool for another (more powerful and elite) discipline, for judgmental purposes, ${ }^{86}$ which is anathema to those considering history as an evaluative discipline. ${ }^{87}$ By contrast, a more integrationist school of historians envision a harmonious relationship with law. In their view, no legal trump exists. History can do what it does very well via reports and expert evidence, which may or may not point up individual responsibility. Law can do what it does thereafter. Richard Evans is clearly within this school. Notably so is Christopher Browning who gave evidence in both the Irving and Zundel proceedings.

\section{Smoking gun or wider evaluation?}

Historians certainly move beyond reiteration of abstract data such as emerges from events, statements and isolated documents. Their entire raison d'etre is the contextualisation and linkage of otherwise apparently idiosyncratic events. ${ }^{8}$ Indeed, as noted, event dismantlement is a typical denier tactic - their only exit route out of the wider historical context. Lawyers may also try to disassemble convergence and context to create doubt, consequently disinclining historians from acting as experts. Such legal deconstruction of historical evidence takes advantage of the historical academy's radar for "complexity and ambiguity". ${ }^{89}$ Lawyers are playing historians at their own game. This might be alleviated by allowing historical witnesses to provide written reports for judges and juries (discussed below). By the same token, it has been noted by historians of their peers that historians ably render obfuscations ${ }^{90}$ leaving the unhelpful conclusion that no one anywhere could ever know anything for sure. This radical scepticism can appear as historians playing lawyers at their own game, trumping them with doubt. Arguably this produces a quasi-history or lawoffice history, specially rendered for courts, the worst of all worlds.

The US historian James Mohr (an expert contributor to a brief in US litigation regarding abortion $)^{91}$ considered that historians teased out compelling interpretations from contexts of "complexity, ambiguity, and paradox" but that such "alternative explanations, mixed motives, and inconvenient facts" were anathema to lawyers. ${ }^{92}$ Historians' misconceived view that lawyers seek the smoking gun arises from misconceptions about legal actors. Lawyers' roles as advisers and as advocates are distinguishable. Advocates certainly spin evidence to a client's advantage. However, as advisers during client consultations, lawyers must deal openly with clients regarding unfavourable issues. Lawyers more clearly resemble historians in the latter setting (even if what they ultimately $d o$ with the evidence will be different in other places). Court is not the only forum within which lawyers operate and it is not a given

85 Rousso, The Haunting Past, n. 74 above.

86 Ibid. p. 53.

87 Potentially, Rousso's position empties of all meaning notions of individual legal responsibility in these particular contexts. P Pezzino, "Experts in truth? The Politics of Retribution in Italy and the Role of Historians" (paper delivered at Strathclyde University, spring 2010).

88 Rosner, "Trials and tribulations", n. 83 above, pp. 152, 154.

89 Ibid. p. 158.

90 Ibid. pp. 155-7.

91 Webster $\mathrm{v}$ Reproductive Health Services 492 US 490 (1989).

92 J C Mohr, "Historically based legal briefs: observations of a participant in the Webster process" (1990) Public Historian 19, p. 22. 
that they are antipathetic to historical method. When queried as to particular interpretations of the past, historians are prone to responding "it is more complicated than that", 93 so lawyers are regularly mocked for their similar stock response to queries of "it depends". Perhaps it is not so much history and law which are incompatible but history and advocacy. ${ }^{94}$

It seems within history there are two key strands which compete: (1) the desire to establish wie es eigentlich gewesen ${ }^{55}$ via thorough empiricism; while (2) simultaneously favouring nuance, probability and uncertainty. ${ }^{96}$ The two strands presumably come together in notions that historians simply try to understand/evaluate what happened. Some lawyers feel that the adversarial system allows them to arrive at some form of truth, ${ }^{97}$ having overcome the barriers presented by doubt and argument. The criminal standard of "beyond reasonable doubt" certainly fuels this and US Federal Rule 702 which concerns evidence admissibility (discussed subsequently) explicitly refers to truth ascertainment. Other lawyers more cautiously consider that evidence points in different directions, the adversarial process illustrates where the preponderant conclusion lies. This is more about persuasiveness and apparent "justness" and it sidesteps potential philosophical cul-de-sacs bedevilling discussions as to what constitutes truth and fact. It also reveals a potential meeting point for history and law by replacing grandiose notions of absolute truth with more helpful notions of plausibility.

\section{Finality v eternal re-examination}

Arguably historians' process of eternal re-examination means that their work never forms safe bases for judicial evidence. This suggests that only experts who can give "final answer" evidence (historians often cite scientists) are sufficiently safe, particularly for criminal proceedings. It seems precarious to base a conviction, and its dire consequences, on work whose future determination could vary. From this perspective, law, unlike history, seeks conclusions, it is not a "process of refinement". 98 In law, there are winners and losers, whereas in social science the argument never ends. ${ }^{99}$ However, historians are mistaken in assuming that other experts provide incontrovertible, definitive answers. In UK murder trials, expert pathologists will always be presented by both the Crown and defence legal teams. Most experts work in constantly evolving areas of knowledge. Tobacco litigation and the asbestosis mesothelioma claims are testament to scientific disputes. No expert evidence is foolproof, nor is it ever the sole evidence. Law also countenances its internal nightmare - wrongful convictions and miscarriages of justice. The long-term appeal process clearly envisages this. In the notorious British "cot-death" controversy, expert evidence previously delivered by a lauded scientist, Professor Sir Roy Meadows, resulted in an unsafe murder conviction. In other contexts, the possibility of revisiting legal judgments is evident, witness the re-opening of criminal cases due to the emergence of DNA evidence. ${ }^{100}$ The

93 J C Williams, "Clio meets Portia: objectivity in the courtroom and the classroom", referred to in Martin, "Historians at the gate", n. 32 above, p. 1535.

94 Martin, "Historians at the gate", n. 32 above, p. 1532.

95 "How it really was", see Leopold von Ranke and the nineteenth-century move to characterising history in scientific, empirical terms.

96 Davidson, "Carlo Ginzburg”, n. 10 above, p. 307; Rousso, The Haunting Past, n. 74 above, pp. 82-3.

97 J Sanders, "Expert witness ethics" (2007) 76 Fordham LR 1539, pp. 1539-43, referring to Susan Haack's "Inquiry and advocacy, fallibilism and finality: culture and inference in science and the law".

98 Martin, "Historians at the gate”, n. 32 above, p. 1524, referring to Bloch's work, The Historian's Craft, n. 14 above; Daubert at 597; and D Abraham, "Where Hannah Arendt went wrong" (2000) 18 Law \& History Review 607 , p. 609.

99 C Perelman, The Idea of Justice and the Problem of Argument (London: Routledge \& Kegan Paul 1963).

100 Sanders, "Expert witness ethics", n. 97 above, fn. 45. 
International Court of Justice statute explicitly refers to revision of judgments and Bosnian counsel in the Bosnia v Serbia case expressed willingness to invoke this provision (as regards Serbian state responsibility for genocide) should new historical evidence come to light. ${ }^{101}$ Perhaps historians' anxieties regarding the possibilities of a judicially skewed and frozen version of the past arises from the emergence, since the 1970s, of perspectivalist history which re-emphasises the importance of respecting diverse opinions. ${ }^{102}$ This is dealt with below but, as an early note, just as science is not the definitive series of interpretations historians often believe it to be, by the same token, historians are not incapable of providing testimony. They are just other experts. ${ }^{103}$ The experience of historians in legal proceedings differs among jurisdictions with particularly negative encounters being recounted from US cases, ${ }^{104}$ possibly attributable to this system's extreme adversarialism. For example, coaching witnesses, often professionally unacceptable in other jurisdictions, is commonplace in the US. It seems particularly misguided and fruitless in a context where the expert is filling a gap for the inexpert coacher.

The relationship between lawyers and historians has not always been so fraught. Both the Nuremberg and Eichmann proceedings generated extensive historical evidence, the latter most notably revealing the full meaning of the infamous Wannsee Protocol. In Irving, both Peter Longerich and Robert Jan van Pelt uncovered new and valuable historical evidence 105 and they, together with Richard Evans, subsequently published important books. ${ }^{106}$ Of course, while law can prompt historical revelations, historical involvement in cases should not be motivated by this tantalising prospect. Indeed, van Pelt's participation in Irving caused him to reflect more broadly upon his established historiographical understandings. ${ }^{107}$ There are concerns that law does not serve wider historical purposes because its remit is so narrow. Concerned with "the provable rather than the probable" it does not demand a "reading between the lines of . . . documents". ${ }^{108}$ However, this does not imply that history wants no relationship with law, it simply yearns for a more complete outcome. The establishment of an evidential standard which draws on the acceptable methodology of the historical academy, and which relates to admissibility or reliability, represents a way forward.

\section{JUDICIALISING THE PAST: HISTORY AS JUDGMENT RATHER THAN EVALUATION}

Over the centuries, shifts in historical practice are detectable. The original classical tradition of argument eventually developed into a judicial model where historians sought to establish the guilt or innocence of historical figures. However, this moralistic, judgmental historiography (with its legal overtones) was ultimately rejected in favour of historical understanding. ${ }^{109}$ The post-1980s trend ${ }^{110}$ for historians to give evidence in contemporary trials regarding Second World War crimes may worryingly suggest a return to the classical

101 M Milanovic, "State responsibility for genocide: a follow-up" (2007) 18 European Journal of International Law 669 , p. 676.

102 Rosner, “Trials and tribulations”, n. 83 above, pp. 145-6.

103 Criticised by Dumoulin, Le role, n. 14 above.

104 H H Tanner, "History vs. the law: processing Indians in the American legal system" (1998-99) 76 University of Detroit Mercy LR 693, p. 694.

105 Evans, "History", n. 68 above, p. 343.

106 Longerich, Unwritten Order, n. 47 above; van Pelt, The Case, n. 52 above; Evans, Lying, n. 22 above.

107 van Pelt, The Case, n. 52 above, pp. 103-4.

108 D Bloxham, Genocide on Trial (Oxford: OUP 2005), p. 221.

109 C Ginzburg, "Checking the evidence: the judge and the historian”, in Chandler et al., Questions, n. 10 above, pp. $290-4$.

110 See generally, H Jones, K Östberg and N Randeraad (eds), Contemporary History on Trial (Manchester: Manchester UP 2007). 
juridical tradition and the moralising of that history. ${ }^{111}$ Crude classifications of individuals as executioners or victims disturb notions of an explanatory discipline. Characterised as a malign "judicialisation of the past", this envisages historians as enslaved into the service of moral and legal forms of judgment, eschewing the subtleties and nuances of the historian's craft. ${ }^{112}$ However, equally, such a characterisation appears to overlook both the social responsibilities of historians and the possibility that law may not leave its fingerprints on historical research after litigation.

\section{Courts as memorial sites}

An alternative interpretation sees courts as providing a context for the instrumentalisation of both law and history by outside politics. ${ }^{113}$ One such political force might be the promotion of a particular national ideological/historical identity. This was clearly the case in the French prosecutions of Klaus Barbie and Maurice Papon, wherein legal definitions of "crimes against humanity" were, due to political imperatives, varyingly recast. Propping up Gaullist myths of national resistance while unpicking the varyingly presented characterisations of Vichy as a racist regime or Nazi puppet was the unpalatable task left to historians dragged into the accordingly difficult issues of proof. ${ }^{114}$ The "duty to remember" might be another political force, with trials as vectors of memory, focused upon redressing past wrongs. An example of memory's performativity was evidenced in the "commemorative ritual" of victims' name-reading against a projection of their photographs during the Papon trial. ${ }^{115}$ This, of course, can produce a Geschichtmüdigkeit - historian fatigue or a "surfeit of eventfulness". 116 Germany, for example, has arguably adopted a posture of "obsessive mindfulness of the past" "117 which appears as a distancing process, saying more about Germany's present than its past. This overt rejection of amnesia can prompt moral judgments (thus explaining its comfort in courts) potentially reconstructing either idealised or demonised pasts. Lipstadt herself said that Irving became "a personal quest for the preservation of truth and memory". ${ }^{118}$ However, as a scholarly reconstruction of the past, history is epistemologically based. Memory, part of existential experience, is "endowed with magical virtues and an aura of human spirit absent from history's accounts". 119 As such, it is transcendental and talismanic, a value rather than an objective phenomenon. In its encouragement of affective emotional relationships with the past, it may impede "a real apprenticeship of the past". ${ }^{120}$ More sinisterly, "[freighting] . . contemporary identity with historical reminiscence" 121 means that memory has capacity to be collectively manipulated and mobilised by those seeking to privilege values and ideals of particular social groups. ${ }^{122}$

111 See Pezzino's reference to his Guardistallo study, “Experts”, n. 87 above, and Dumoulin, Le role, n. 14 above, generally.

112 Rousso, The Haunting Past, n. 74 above, pp. 50, 52.

113 Evans, "History", n. 68 above, p. 332.

114 Fink, "New historian", n. 9 above, pp. 139-40, commenting on Golsan, and T O'Donnell, "The trial of Maurice Papon: the night and fog of France's Vichy past" (2002/2003) 6(2) CIL 133.

115 N Wood, “The Papon trial in an "era of testimony" in R J Golsan (ed.), The Papon Affair (New York: Routledge 2000), pp. 96, 97.

116 P Mandler, "The responsibility of the historian" in Jones et al., Contemporary History, n. 110, p. 13.

117 Douglas, The Memory, n. 29 above, p. 220. See also M Fulbrook, German National Identity after the Holocaust (Cambridge: Polity Press 1999), p. 230.

118 V Dodd, "How the web of lies was unravelled", The Guardian, 12 April 2000.

119 Rousso, The Haunting Past, n. 74 above, p. 2.

120 Ibid. pp. 2, 3, 7, 4, 16. See Golsan, The Papon Affair, "Introduction”, n. 115 above, p. 25, outlining similar sentiments from Todorov, Conan and Maier.

121 Mandler, "The responsibility", n. 116 above, p. 19.

122 K-G Karlsson, "Public uses of history in Europe" in Jones et al., Contemporary History, n. 110, p. 36. 
This, in turn, might explain why certain eras are of more popular interest than others (see references to the Holocaust's "awful majesty") ${ }^{123}$ because they easily tap into fantasies and imaginations. They permit a continuing history or a "living through history" without the attendant dangers or implicatory overtones. 124

Unreflective uses of oral sources confuse history and memory ${ }^{125}$ which is anathema to explicatory historians anxious about becoming law's accomplice in agitating memory ${ }^{126}$ particularly when there are human consequences. For them, legal categorisation is a blunt condemnatory instrument, leaving unrecognised the very complex situations and choices facing individuals very long ago. It casts aside how specific understandings of morality at particular times produced or resisted particular behaviours. ${ }^{127}$ This "why" of events means that it is always more complicated. ${ }^{128}$ Perhaps there is a need for historians to develop a more sophisticated comparative historiography of public history, ${ }^{129}$ although this article favours maintaining the same intellectual rigour for testimony as for academic publishing.

There is undoubtedly more likelihood of an expert witness feeling "cornered"130 in cross-examination in criminal cases. Even if centrally important, historical testimony is but one piece of evidence in a very complex mosaic. At the same time, expert historians rather than non-experts are preferable sources ${ }^{131}$ and perhaps the description of historical testimony as simply providing a secondary "point of departure for enquiries" which are then developed by judicial analysis ${ }^{132}$ is more helpful. Further, criminal trials represent only one particular version of proceedings regarding the Second World War/Holocaust. Holocaust denial trials represent a separate (sometimes criminal) category, where law is being invoked to police history. ${ }^{133}$ Classic "hate speech" or Holocaust denial trials routinely involve the imposition of criminal penalties and attendant judicial condemnations of an accused. In the German trial of Robert Althams (who was filmed in an Auschwitz gas chamber declaring it "a gigantic lie") the judge declared him a "dangerous intellectual arsonist". 134 Such symbolic Durkheimian banishments exile negationists while simultaneously, reassuringly (but perhaps wrongly) confirming that certain (anti-Nazi) values are identifiable with that exiling society. ${ }^{135}$

Finally, there is a case such as Irving where the Holocaust both intercedes and recedes in prominence as a contextual anchor. Irving was not a criminal trial. Oscillating between empirical detail and epistemological reflection, it potentially allowed for more nuanced analysis. The historical experts were being asked about Irving's modus operandi, including his

123 Mandler, "The responsibility", n. 116 above, p. 15.

124 Ibid. pp. 13-14.

125 Pezzino, "Experts", n. 87 above, p. 4.

126 Rousso, The Haunting Past, n. 74 above, pp. 2, 12. See also Evans, "History”, n. 68 above, pp. 333-4.

127 A Kessler-Harris, "Legal theory and gendered history" (2010) 19 Columbia Journal of Gender and Law 125.

128 For example, regarding Papon, Rousso was critical of historical experts' non-elaboration regarding Vichy officials' assistance to the Résistance; Rousso, The Haunting Past, n. 74 above, pp. 63, 73.

129 Fink, "New historian", n. 9 above, p. 147.

130 See A Kessler-Harris, "Equal Opportunity Employment Commission v Sears, Roebuck and Company: a personal account” (1986) 35 Radical History Review 57, p. 74.

131 Fink, "New historian", n. 9 above, p. 141, commenting on Ginzburg's criticisms of judicial behaviour, The Judge, n. 10 above, pp. 110-19.

132 Pezzino, "Experts", n. 87 above; Bloch, The Historian's Craft, n. 14 above, p. 3.

133 See D McGoldrick and T O’Donnell, "Hate-speech laws: consistency with national and international human rights law" (1998) 18 Legal Studies 453.

134 Referred to in R Kahn, "Sentencing at Political Trials: The Case of Holocaust Revisionism” (paper presented at Sentencing and Society: An International Conference, Glasgow, 24-26 June 1999).

135 Ibid. 
obfuscations, the nature of groups he associated with and the professional standards of conscientious historians. This seems entirely consonant with the expertise held by historians. Irving concerned defamation, an area (unlike Holocaust denial or defaming the dead) not depending for its existence upon the Holocaust's occurrence. Potentially prurient interest in the Holocaust's often pornographically violent detail was neither encouraged nor relevant. However, although Irving concerned a civil wrong, the finding impugned Irving's professional method as one which manipulated and distorted in order to facilitate his antiSemitic and racist agenda. Mr Justice Gray's condemnatory conclusions evoked a prisoner's sentencing. Thus, while it is probably true that historians might feel safer in civil proceedings, it is not entirely clear that the Irving trial was the "purest" example thereof.

\section{Courts as historical didactic sites}

The judicially sited denunciation is notionally allied to re-conceptualisations of courts as educational mises en scène which can also disincline historians from participating in cases. Statements stressing Irving's didactic value came from Yad Vashem ${ }^{136}$ and Lord Janner of Braunstone QC, chair of the UK Holocaust Educational Trust. ${ }^{137}$ Indeed, on one reading, Irving exposed the modus operandi of revisionist historians, ${ }^{138}$ which in itself might be revelatory and illuminating. ${ }^{139}$ However, arguably, courts simply deliver verdicts not grand educational narratives. To assume a pedagogical judicial function implies a view that events are structured by repeating and inevitable recyclable logic. Assuming that individuals are immutably identical to their ancestors overlooks the fact that different political opportunities are presented by differing times. Further, didactic imperatives inspire Arendtian concerns regarding the Eichmann trial and fears of Soviet-style show trials. ${ }^{140}$ Indeed, for historians, didacticism is potentially imprisoning or even distorting of future historical interpretations. Long-term historical confusions as regards the so-called Führerbefehel (Führer order) and the timing of the Final Solution ${ }^{141}$ arose from the Einsatzgruppen case. Future historical interpretations potentially become limited to the legal conclusions of the court record. Yet as the sceptical historian Donald Bloxham notes, among law's specific ends, "the historical record is a wild card". ${ }^{142}$ Similarly, utilising Holocaust history, including Holocaust trials, to provide a distinctive sense of Jewishness (in place of the synagogue) seems problematic, ${ }^{143}$ distorting and incomplete. Historical witnesses would simply be adding ornamental, academic lustre to proceedings offering nothing to historical understandings. Although a concern in perpetrator trials, it comes into sharper focus in the Holocaust denial context. Indeed, Zundel's criminal "false news" trial was denounced as displaying "the perils of relying on legal dramaturgy as a means of buttressing the integrity of history". 144

136 P Reeves, "State built on suffering breathes a collective sigh of satisfaction", The Independent, 12 April 2000.

137 I Burrell, "Rascist. Anti-Semite. Holocaust denier. How history will judge David Irving", The Independent, 12 April 2000.

138 Although he doubted tribunals' value, Vidal-Naquet asserted “Confronting a paper Eichmann, one should respond with paper", Assassins, n. 21 above, p. 76.

139 See E Zuroff's comments (director of the Jerusalem Simon Wiesenthal Centre), in Reeves, "State built on suffering", n. 136 above.

140 Bloxham, Genocide, n. 108 above, p. 225.

141 H Earl, The Nuremberg SS Einsatzgruppen Trial (Cambridge: CUP 2009), pp. 184-216.

142 D Bloxham, "The Holocaust in the courtroom" in D Stone (ed.), The Historiography of the Holocaust (Basingstoke and New York: Palgrave Macmillan 2005), p. 398, although he refers principally to criminal trials.

143 Mandler, "The responsibility", n. 116 above, pp. 18-19.

144 Douglas, The Memory, n. 29 above, p. 225. 
Nevertheless, despite all of the concerns expressed above, the Holocaust context should not defeat the establishment of a general judicial standard for historical evidence. In the US, in particular, historians have been called to give evidence in a wide range of both public and private interest litigation ${ }^{145}$ including tobacco litigation, ${ }^{146}$ water rights, ${ }^{147}$ trademark disputes, ${ }^{148}$ voting rights, deportation/denaturalisation, and tort actions against the leadpaint industry. ${ }^{149}$ Huge controversies, intra-historian strife and debates as to the ethics of experts have ensued.

\section{DE-jUDICIALISING HISTORY}

As previously noted, not all law-history interactions are replete with anxiety. Courts determine verdicts; historians reconstruct relationships "between individual lives and the contexts in which they unfold". ${ }^{150}$ Some hybrid models manifest a complementarity. The UK Spoliation Advisory Panel which deals with Nazi property expropriations, and thus has serious regard to legal provisions, is also sensitive to the wider social context of alleged expropriations and both lawyers and historians (including Richard Evans) are panel members. Further, in civil litigation, the outcome relies on the balance of probabilities given the preponderance of the evidence. This is much closer to historical readings of evidence.

As previously noted, historical research has also been commissioned by companies which may uncover complicity in Nazi crimes deserving of legal redress. Commissioning such historical studies might even itself perform some "admission restitution". ${ }^{151}$ However, while broadly framed historical investigations might bolster moral arguments and contribute evidentially, they should be decoupled from the essence of the litigation. For example, the official Dutch inquiry into Srebrenica ${ }^{152}$ or the Saville tribunal on Bloody Sunday ${ }^{153}$ resulted from public controversy, potentially placing pressures on historians to reach politically desirable conclusions. Confusion occurs if the evidence of historians, who are not state prosecutors or court officers, is spun into evidence resulting in legal liability, without having passed through the crucible of court proceedings. If it is true that "truth sets in motion other consequences", then historians must eventually make way for judges, as desires for historians to "do justice" are problematic. ${ }^{154}$ Declaring individuals' acts does not automatically impose legal liability without further intervention by legal agents. To enunciate and evaluate events, and to judge and condemn them are quite different tasks requiring demarcation.

Allowing experts to submit written materials in advance of hearings might provide a bulwark for historical evidence against legal onslaughts. Indeed, under the English Civil

145 Martin, "Historians at the gate", n. 32 above, p. 1518.

146 Covert v Liggett Group Inc. 750 F Supp 1303 (MD La 1990), Rosner, “Trials and tribulations”, n. 83 above, pp. 138-9.

147 Denson v Stack 997 F2d 1356, 1363-8 (11th Cir 1993).

148 Harjo v Pro-Football Inc. 50 USPQ 2d (BNA) 1705 (1999).

149 Rosner, “Trials and tribulations”, n. 83 above, pp. 137-8.

150 Ginzburg, "Checking the evidence”, n. 109 above, pp. 300-1.

151 G Feldman, "The historian and Holocaust restitution: personal experiences and reflections" (2005) 23 Berkeley Journal of International Law 347, pp. 354-5; O Rathkolb, "Private industry and banking commissions and the Holocaust era assets debate" (2002) Study Germanica et Austraica 2, p. 48. http://sga.euweb.cz/002/ debata/download/rathkolb-002.pdf.

$152 \mathrm{H}$ Blom, "Historical research where scholarship and politics meet: the case of Srebrenica" in Jones et al., Contemporary History, n. 110, p. 104.

153 P Bew, "The Bloody Sunday tribunal and the role of the historian” in Jones et al., Contemporary History, n. 110, p. 62.

154 Pezzino, “Experts”, n. 87 above, referring to Maier's work. 
Procedure Rules referred to below, the presumption is that in the case of evidence from a single joint expert (one jointly selected and approved by the parties), the written evidence will displace oral testimony. The supply and use of affidavits by historians in the German Auschwitz trials of 1963-65 was noted with approval and these were later published. ${ }^{155}$ In Irving, van Pelt's 770-page report introduced the nuance he felt was denied in his oral testimony being neither skewed by questions nor misleadingly streamlined by him. ${ }^{156}$ The credibility of such written material would be enhanced if based on pre-litigation work. Arguably, intricately technical and dense reports might be less helpful in jury proceedings, however, such arguments relate to juries, not judges and courts in general.

\section{HISTORICISING LAW}

In Nuremberg and Eichmann, the input of historians was not significant whereas in Irving, the historical guild asserted itself via the defence expert witnesses. ${ }^{157}$ These historians were focused on illustrating the existence and fortification of the highest professional (as opposed to philosophical) standards. van Pelt commented on the pride he felt during a later trip to Auschwitz, in having represented history in a British High Court. ${ }^{158}$ Adherence to methodological standards and intellectual rigour emerged as indispensable requirements for guild membership. Further detail on what passes for historical intellectual rigour will be discussed. In short, Irving's behaviour was considered beyond the pale. His prejudiced methodology was considered by historians to be bringing them into disrepute, requiring professional excommunication via legal judgment. The successful defence of justification indirectly aided this exiling. In Irving, history was not judicialised so much as law was historicised. The case was brought by a historian invoking a legal claim against another historian, in contrast with Holocaust denial legislation where law is more clearly intruding into history.

\section{Ideological advocacy and preserving Clio's integrity}

\section{AVOIDING THE CONTAMINATION OF THE JUSTICE PROCESS BY SKEWED TESTIMONY}

The Irving expert witnesses exhibited differences in their approaches. Defence solicitor Anthony Julius instructed the experts that their duties were to the court, offering technical assistance. They had to be objective, adhering to the terms of their oath ${ }^{159}$ - robust, cool professionals. Yet, van Pelt undertook the oath by swearing on his grandfather's Bible which had accompanied his family into hiding from the Nazis. He also had with him his grandmother's yellow star and last letters from her brother after whom he was named. van Pelt defiantly maintained that his report was compiled without prejudice for the defendant and against the plaintiff, declaring his loyalty with Auschwitz's victims as against their murderers. ${ }^{160}$

The myth of the disinterested historical academy engaged in mortal combat with the decidedly interested advocate is a powerful one and, undoubtedly, particular tensions exist

155 H Krausnick, H Buchheim, M Broszat and H-A Jacobsen, Anatomy of the SS State (New York: Walker 1968). Although perhaps this only worked because it was done when the history of the Nazi period was still evolving:

Rousso, The Haunting Past, n. 74 above, p. 66.

156 van Pelt, The Case, n. 52 above, p. 456.

157 Evans, "History", n. 68 above, p. 341.

158 van Pelt, The Case, n. 52 above, p. 487.

159 Evans, Lying, n. 22 above, pp. 7 and 30.

160 www.archive.org/stream/PeltReport/report_djvu.txt. 
when historians give themselves over to acting as the advocate's evidential tool. ${ }^{161}$ Historical experts should be neither evangelists nor mere amanuenses but rather estimators of the past. Expert witnesses have been denounced as whores, ${ }^{162}$ yet the contrasting but naive belief in their possible virginity persists. Even if history is purely an explanatory discipline, history and historians are not value-free. Personally committed historians can provide reliable testimony which assists in the administration of justice. Their mettle is judged by whether these commitments distort their research. Unreliable "junk history" which impedes the legal process must be distinguished from perfectly valid, perspectival history.

One route for judges might be to turn to the accepted methodology of a discipline. However, historians disagree on methodology 163 and "guilds" are potentially prescriptive and imprisoning. Nevertheless, just as technology has gifted an "abundance and heterogeneity" of sources, so it necessitates an acknowledgment or ranking system of the varying historical values of documentaries as against official government archives. ${ }^{164}$ Without being sidetracked by discussions concerning the nature of knowledge and the philosophy of history, judges require criteria for assessing the weight of historical evidence to ensure "intellectual due process" and that legal conclusions are evidentially sound. ${ }^{165}$ Thus, a legally created standard for experts seems attractive and the options are either admissibility or reliability tests.

\section{Junk history and its exclusion: the methodological test}

The worst that can be said about an expert opinion is not that it is a lie . . but that it is unreasonable, that no competent expert in the field would hold it. ${ }^{166}$

Certain possibilities exist with a US-style "gatekeeping" test. Daubert v Merrell Dow Pharmaceuticals Inc. ${ }^{167}$ (and its legal progeny) sought to exclude "junk science" from courts. Similarly, harm is done to legal process by "law-office" history 168 (to say nothing of the harm to history). Daubert focused on adversarial bias evident in: venal hired guns (conscious bias); those naturally sympathetic to their employer (unconscious bias); and those experts willing to limit their evidence to a particular (usually hiring) perspective (selection bias). ${ }^{169}$ Given the allegations of "ersatz history" in denial proceedings, Dauberts tests could be applied to exclude "junk history" following Kumbo Tire Co Ltd v Carmichael70 i.e. historical evidence based on unreliable methodology. ${ }^{171}$ Rule 702 of the US Federal Rules of Evidence (amended via caselaw) admits expert testimony, if it is based upon sufficient facts or data, and is the product of reliable principles and methods which the witness has applied

161 T Haskell and S Levinson, "Academic freedom and expert witnessing: historians and the Sears case" (1988) 66 Texas LR 1629, pp. 1649, 1657. See also A Kessler-Harris, "Academic freedom and expert witnessing: a response to Haskell and Levinson” (1988) 67 Texas LR 429.

162 J Morgan Kausser, "Are expert witnesses whores? Reflections on objectivity in scholarship and expert witnessing” (1984) 6(1) Public Historian 5.

163 Goodman, "Slipping through", n. 80 above, p. 857.

164 Rousso, The Haunting Past, n. 74 above, pp. 35-6.

165 S Brewer, "Scientific expert testimony and intellectual due process" (1998) 107 Yale LJ 1535, p. 1540.

166 Sanders, "Expert witness ethics", n. 97 above, fn. 1, quoting S R Gross, "Expert evidence" (1991) Wisconsin LR 1113, p. 1178.

167509 US 579 (1993) and 43 F3d 1311 (9th Cir 1995).

168 Martin, "Historians at the gate", n. 32 above, pp. 1525-6.

169 D E Bernstein, "Expert witnesses, adversarial bias, and the (partial) failure of the Daubert revolution" (2008) 93 Iowa LR 451, 453-8.

170526 US 137 (1999). For recent discussion, see Lear v Fields 226 Ariz 226, 245 P3d 911, 599 Ariz Adv Rep 37 (Ariz App Div 2 Jan 12 2011).

171 Ibid. 141. Goodman, "Slipping through", n. 80 above, p. 826. 
reliably to the facts of the case. Following Daubert, Kumbo Tire acknowledged relevant factors could include peer review ${ }^{172}$ and publication, widespread acceptance within the relevant discipline's community, and a particular theory/technique's testing and error rate (including the existence and maintenance of standards controlling its operation). ${ }^{173}$ Kumbo Tire noted Daubert's gatekeeping requirement existed to ensure that an expert:

whether basing testimony upon professional studies or personal experience, employs in the courtroom the same level of intellectual rigor that characterizes the practice of an expert in the relevant field. ${ }^{174}$ [emphasis added]

Courts are clearly trying to avoid imposing their own standards on non-legal disciplines. There is not one set of rules for expert journal publications and another for affidavits or written testimony. Requirements of peer review are helpful for avoiding scholars resting on reputations despite later dips in judgment. Further, if the evidence was based on research findings deriving from work funded by a major research council, for example, the UK Arts and Humanities Research Council, then that too would testify to its satisfaction of academic thresholds. Historians may not agree detailed methodological standards but Irving clearly evidenced the existence of a baseline. If experts represent themselves and the knowledge their field has regarding a particular topic, ${ }^{175}$ then Kumbo Tire's inclusion of peer review is attractive. However, a gatekeeping rule relies on adversarial challenge for its activation, without which the evidence will be admitted. Further, Irving actually did have certain historical credentials somewhat neutralising Dauberts potency, thus it may be best to confine such a qualitative test to matters of credibility and relevance, to be dealt with later in proceedings. ${ }^{176}$

\section{Can we put Clio on the Clapham omnibus?}

"Ideological scholarship" can compromise expert integrity. Rather than lying, experts are persuaded away from ambiguity and contrary evidence in favour of unfractured, simplistic narratives. Indeed, in Brown $\mathrm{v}$ Board of Education, one eminent historian felt compromised in fulfilling Thurgood Marshall's legal aims. ${ }^{177}$ Perhaps in the school desegregation cases plaintiffs' witnesses considered themselves morally in the right, justifying weighted adversarialism. ${ }^{178}$ This might be equally true of gender discrimination cases. ${ }^{179}$

Arguing that historical witnesses are simply providing legal evidence based on history, rather than "doing history" is a neat distinction. ${ }^{180}$ Indeed, as previously mentioned, James Mohr signed a particular amicus brief regarding abortion because it was closer to his historical view rather than that of the other side. ${ }^{181}$ However, such experts have been chosen due to their professional expertise and assumptions that they adhere to certain standards. It

172 S Haack, "Peer review and publication: lessons for lawyers" (2007) 36 STETLR 789.

173 See n. 170 , at $149-50$.

174 See n. 170 , at 152 .

175 Sanders, "Expert witness ethics", n. 97 above, p. 1558.

176 E.g. see C Pede "The Trail of the Fox", book review (1996) 151 Military LR 230. However, Goodman, "Slipping through", n. 80 above, pp. 869-71, notes that Irving's method had not been subject to rigorous peer review prior to the case.

177 R Kluger, Simple Justice, p. 640, referred to in Martin, "Historians at the gate", n. 32 above, p. 1528.

178 Sanders, "Expert witness ethics", n. 97 above, pp. 1559-60

179 D A Farber, "Adjudication of things past: reflections on history as evidence" (1998) 49 Hastings LJ 1009. See also his referencing of the trial judge's critique of governmental expert witnesses in US v Virginia 518 US 515 (1996) 1016-17.

180 Mandler, "The responsibility", n. 116 above, pp. 15-16; Pezzino, "Experts", n. 87 above. See also D J Rothman, "Serving Clio and client: the historian as expert witness" (2003) 77 Bulletin of the History of Medicine 24, p. 44.

181 Mohr, "Historically based legal briefs", n. 92 above, p. 25. 
is problematic if they have been engaged simply for the reflected glow of their "professional aura" upon proceedings. Further, for a historical expert in his or her evidence to issue a disclaimer as to that evidence not being "truly historical" is confusing and disorientating. ${ }^{182}$

In judging what passes for "intellectual rigour" in the historical field, lawyers are trying to put Clio on the Clapham omnibus. In Irving, after hearing the historical experts, Mr Justice Gray invoked an "objective historian" standard. This required that historians:

1) treat sources with appropriate reservations;

2) not dismiss counter-evidence without scholarly consideration;

3) be even-handed in the treatment of evidence, eschewing "cherry-picking";

4) clearly indicate any speculation;

5) not mistranslate documents or mislead by omitting parts of documents;

6) weigh the authenticity of all accounts, not merely those that contradict favoured views; and

7) take the motives of historical actors into consideration. ${ }^{183}$

Such reliability tests clearly echo judicial directions to juries. This standard avoided an alien grafting exercise as it emerged from a case where both historians and lawyers played prominent roles. The test's allusions to integrity support its recasting as a "conscientious historian" standard. ${ }^{184}$ Alternatively, renaming it as the "reliable historian" standard185 emphasises that the expertise is being viewed both on its terms and as regards its reliability for another discipline. This standard simply says this evidence is reliable, not definitive. Unfortunately, this test relies on skilful cross-examination or considerable judicial wherewithal as regards historical methodology. This may emphasise the appeal of a barappointed historian, an issue discussed below. It does not mean that such a standard is so unworkable as to be rejected out of hand.

However, just as Mr Justice Gray's standard says something about the reliability of certain histories for law, it also implies something about one historian's reliability for other historians. As such, it moves (perhaps uncomfortably) close to notions of a normative historical methodological standard. Apart from the straightforward worries regarding a perceived imperial expedition by law onto the territory of history, normatively based understandings of objective historical methodology are also controversial and provoke intra-historian anxieties. There are two prominent aspects to these controversies, the debates over whether there is objective history and the notion of a historical guild.

\section{Avoiding over-exclusivity: distinguishing between ideological and perspectival scholarship}

As noted, gatekeeping tests can be over-exclusive, potentially silencing and excluding new voices in scholarship, leaving courts with an incomplete historical picture. Tensions exist between the objectivist ${ }^{186}$ and relativist ${ }^{187}$ historical schools. Objectivists maintain a "truth-

182 Ginzburg, The Judge, n. 10 above, p. 7.

183 W E Schneider, "Past imperfect” (2001) 110 Yale LJ 1531, pp. 1534-5.

184 Ibid. pp. 1539-40.

185 Goodman, "Slipping through", n. 80 above, p. 838, referring to the work of M Howell and W Prevenier, From Reliable Sources (Ithaca and London: Cornell UP 2001), p. 2.

186 See G Elton, The Practice of History (Sydney: Sydney UP 1969) and T L Haskell, “Objectivity is not neutrality: rhetoric vs. practice in Peter Novick's That Noble Dream” (1990) 29(2) History and Theory 129; cf. Novick, That Noble Dream, n. 8 above. See generally, R Evans, In Defence of History (London: Granta 2000), ch. 8, “Objectivity and its limits".

187 Farber, "Adjudication of things past", n. 179 above. See E Hallett Carr, What is History? and its partial critique in Evans, In Defence, n. 186 above, pp. 224-30. 
seeking" approach and form a minority nowadays. By contrast, relativists or "perspectivalists", 188 favour enhanced and more complete historical narratives achieved by introducing new progressive perspectives, notably those of feminists or critical race scholars. Rejecting notions of absolute truth and orthodox views of historical events/phenomena, ${ }^{189}$ and convinced by Foucauldian theories regarding relations between power and knowledge, postmodernists in particular have advocated new approaches to analysing the Holocaust. ${ }^{190}$ Rethinking texts and narratives, encouraging historians to take "their surface patina more seriously", ${ }^{91}$ chimes with those rejecting central tenets of strict positivism who question the existence of a transparent relationship between historical evidence and historical reality. ${ }^{192}$ Although concerns persist that meta-principle is simply being replaced by extreme relativism 193 or radical scepticism, and while relativism/perspectivalism is often accused of revisionism and political correctness, openly relativist views of history are surely preferable to "falsehoods, myths, and ideologically biased narratives masquerading as truths under the banner of objectivity". ${ }^{194}$

Providing it countenances self-criticism and challenge, "committed history is not necessarily bad history". 195 Of course, relativist historians might simply be advocates using their professional authority to conceal their willingness to construct narratives selectively. 196 However, occupying an unorthodox philosophical position does not inevitably result in either questionable professional standards or intentional distortion in pursuit of an ideological agenda. ${ }^{197}$ While the existence of forged documents, like the Protocols of the Elders of Zion and TB47, is historically important, this says nothing about the value of their content. ${ }^{198}$ In fact, Irving might better be described as a misinforming false objectivist. ${ }^{199}$

Mr Justice Gray's standard should not impede the use of evidence for progressive causes. Perspectival historians can make balanced assessments of evidence. ${ }^{200}$ Rather than looking for the smallest mistake (as noted, a key denier tactic), the conscientious/reliable historian standard detects patterns of errors, Irving's key downfall. ${ }^{201}$ The standard is not perfect but its schema is attractive in its clarity and sensitivity to social-scientific method. All of the Irving defence experts were tested in court and none emerged as a liar or politically charged distorter of the sources. Notably, van Pelt's report stood on its own terms, as did his transparent analysis of the hierarchy of historical sources. ${ }^{202}$

188 R E Schiller, "The strawhorsemen of the Apocalypse: relativism and the historian as expert witness" (1998) 49 Hastings LJ 1169, p. 1173.

189 Ibid. pp. 1173-4; H White, "The politics of historical interpretation: discipline and de-sublimation" (1982) 9(1) Critical Enquiry 113.

190 R Eaglestone, The Holocaust and the Postmodern (Oxford: OUP 2004) and A Milchman and A Rosenberg, Postmodernism and the Holocaust (Amsterdam/Atlanta GA: Rodopi 1998).

191 Evans, In Defence, n. 186 above, p. 248.

192 “A rejoinder to Arnold I. Davidson”, Ginzburg, Questions, n. 10 above, p. 321.

193 See the critiques of the works of Stanley Fish discussed below.

194 Schiller, “The strawhorsemen”, n. 188 above, p. 1169.

195 Evans, "History”, n. 68 above, p. 344.

196 Schiller, “The strawhorsemen”, n. 188 above, p. 1175.

197 Goodman, "Slipping through", n. 80 above, p. 827; Martin, "Historians at the gate", n. 32 above, p. 1548.

198 Ginzburg, The Judge, n. 10 above, pp. 17 and n. 109 above, p. 295.

199 Schiller, “The strawhorsemen”, n. 188 above, p. 1177.

200 Schneider, "Past imperfect", n. 183 above, p. 1540-1.

201 Ibid. pp. 1543-4.

202 "Preface", in electronic edition of van Pelt's report, n. 160 above. 


\section{Codes for experts?}

Codes of conduct for expert witnesses appear attractive. ${ }^{203}$ New South Wales (NSW) has developed such a code which complements its Uniform Civil Procedure Rules 2005. ${ }^{204}$ The key stipulation that experts are not advocates for parties but instead owe their prime duty to the court ${ }^{205}$ chimes with Part 35 of the Civil Procedure Rules (CPR) (England and Wales). ${ }^{206}$ The NSW code focuses on removing hired guns and thereby perhaps removes potential ethical conundrums for witnesses. ${ }^{207}$ The accompanying rules (concerning both expert reports and oral evidence) emphasise judicial control over the giving of expert evidence, restrict expert evidence to that which is reasonably required (thereby avoiding unnecessary obfuscation) and limit its use to as few experts as possible. ${ }^{208}$ The preference is clearly that an expert be engaged jointly by the parties, ${ }^{209}$ although if impossible, separate experts can (only with their consent) be appointed. ${ }^{210}$ Under the NSW rules, if more than one expert is involved in proceedings, the court may order an expert conference (with or without parties' attendance) and the preparation of a joint report specifying matters agreed and not agreed. ${ }^{211}$ In such situations, experts must endeavour to reach agreement and must not act on any instruction or request to withhold or avoid agreement with each other. ${ }^{212}$ This might eliminate gratuitous over-complication. Evidence of other experts on the same issue will not be permitted without leave of the court ${ }^{213}$ and courts may even issue directions providing for the instruction of a court-appointed expert. ${ }^{214}$

Expert witnesses must be provided with the code. Under the NSW rules, unless otherwise ordered, 215 evidence may not be received without acknowledgment from experts of having read and agreed to be bound by the code. ${ }^{216}$ This practically amounts to an additional oath and is a clear example of an ethically influenced procedure. In expert reports before English courts, details must include the person's qualifications as an expert on the report's subject, the facts and material instructions on which the report's opinions are based, reasoning for opinions expressed, whether issues fall outside expertise 217 and the literature or other materials utilised. Reports should include brief summaries. If the expert believes the report may be incomplete or inaccurate without some qualification, that qualification must be stated. If the expert considers that his or her opinion is not conclusive, due to insufficient research or data, for example, again this must be stated. More interestingly, if an expert changes his or her opinion on material matters after providing an

203 Sanders, "Expert witness ethics", n. 97 above; D M Paciocco "Unplugging jukebox testimony in an adversarial system: strategies for changing the tune on partial experts" (2009) 34(2) Queen's LJ 565.

204 Sched. 7, of the 2005 NSW Uniform Civil Procedure Rules: www.legislation.nsw.gov.au/scanview/ inforce $/ \mathrm{s} / 1 /$ ?SRTITLE $=\% 22$ Uniform $\% 20$ Civil $\% 20$ Procedure $\% 20$ Rules $\% 202005 \% 22 \&$ nohits $=y$. For a critique of this approach see G Edmond, "After objectivity: expert evidence and procedural reform" (2003) 25 Sydney LR 131.

205 Sched. 7 Part 2.

206 In particular, see rule 35.3 "overriding duty to the court".

207 Sanders, "Expert witness ethics", n. 97 above; p. 1568.

208 NSW rule 31.17.

209 See also the CPR 35.4 and 35.7 and Practice Direction (PD) 35, para. 7.

210 See the rule on pre-appointment approach - NSW rule 31.37.

211 NSW rule 31.24.

212 NSW Sched. 7 Parts 4 and 5.

213 NSW rule 31.44.

214 NSW rule 31.46.

215 See NSW rule 31.35 re timing and sequence of evidence.

216 NSW Rule 31.23; cf. SCR Part 39, rule 2.

217 CPR PD 35, paras 2.4 and 3.2. 
expert's report, the expert must forthwith provide the engaging party (or their legal representative) with a supplementary report to that effect. ${ }^{218}$

The requirement of an oath varies among European jurisdictions ${ }^{219}$ but awareness of the English code is now mandatory for experts. 220 The "Statement of Truth" required of experts under English rules has been recently revised, ${ }^{221}$ apparently imposing a greater onus on experts to distinguish between facts and matters within their own knowledge and those which are not. A change is also evident in the terminological shift from an expert undertaking that the facts stated are "confirm[ed]" to be true rather than "believe[d]" hinting at a more serious understanding of the responsibilities of experts to the court. ${ }^{222}$

\section{THE HISTORICAL GUILD}

This article has eschewed normative standards of epistemological method or historical truthfulness in favour of standards which favour the acceptable practices of the professional historical community. Normative arguments allow negationists opportunities to sustain their biased arguments. ${ }^{223}$ By contrast, Mr Justice Gray's standard's attractiveness lies in its transparency and its assessment of reliability by a particularly expert interpretive community. Stanley Fish has also christened such communities as guilds and notions of "guild practice" are helpful. This assumes the guild's position is tenable, usually via extensive research: but does this imply a normative dimension to the guild's standards?224 Although Mr Justice Gray's standard might be reflective of some normative expectations within the historical guild, it is not prescriptive in this regard. It is not focused on history for historians but rather the reliability of historical evidence in the court process. Of course, if Holocaust deniers, using Irving's method, overtook the historical guild, its input might become questionable. However, questioning the guild's authority could arise from positive engagement with particular political, moral or economic perspectives, rather than on the basis of some "higher" authority. ${ }^{225} \mathrm{Mr}$ Justice Gray's test, drawing as it did on expert evidence concerning historical methodology, endorses processes producing peer-validated results rather than teaching moral philosophy. This embracing of professional practices echoes Daubert/Kumbo Tire evidential meta-theories. Alongside models for selecting bar-appointed historians (discussed below) this reinforces notions of a guild. Such tests simply concern the professional/public dimension of expert testimony, stepping aside from intra-disciplinary

218 NSW rule 31.27 and Schedule 7 Part 5. See, similarly, CPR PD 35, para. 2.5.

219 R Verkerk, "Comparative aspects of expert evidence in civil litigation" (2009) International Journal of Evidence and Proof 167, pp. 172-3.

220 See the Declaration of Awareness as regards the CPR, PDs and the Protocols. An example of the new format for expert reports is available at www.michael-gerard.co.uk/blog/briefings/changes-to-the-civil-procedurerules-experts/.

221 The previous version read: "I confirm that insofar as the facts stated in my report are within my own knowledge I have made clear which they are and I believe them to be true, and that the opinions I have expressed represent my true and complete professional opinion." The new version reads: "I confirm that I have made clear which facts and matters referred to in this report are within my own knowledge and which are not. Those that are within my own knowledge I confirm to be true. The opinions I have expressed represent my true and complete professional opinions on the matters to which they refer.": CPR PD 35, para. 3.3.

222 See the recent decision of Jones $\mathrm{v}$ Kaney [2011] UKSC 13 regarding the end of immunity for experts and the Law Commission Report, Law Com. No 325, regarding criminal evidence and the draft Criminal Evidence (Experts) Bill.

223 S Fish, "Holocaust denial and academic freedom" (2001) 35 Valparaiso University Law Review 499, p. 513.

224 R Weisberg, "Fish takes bait: Holocaust denial and post-modernist theory" (2002) 14 Law \& Literature 131, p. 140. See also R Weisberg, Vichy Law and the Holocaust in France (New York: New York UP 1998).

225 Fish, “Holocaust denial”, n. 223 above, p. 513. N Spearing, "Don't go changing: on Richard Weisberg's critique of Stanley Fish and Holocaust denial” (2008) 20 Law \& Literature 318, p. 337. 
philosophical debates ${ }^{226}$ which can continue unimpeded. Guilds are not static monoliths but vibrant communities capable of re-inventing their values and practices which others then privilege and rely upon because they comport with the aims, objectives and attitudes of their projects. $^{227}$ Neither the historical guild nor communities which use law are neutral. However, while a guild creates corporate coherence, it limits autonomy - is this problematic?

\section{Guild limitations on expert testimony and academic freedom}

Henry Rousso's refusal to testify at Papon's trial sprang from a desire to preserve his freedom of speech. He refuted the notion of a guild because he did not see his approach as the only ethical one and, indeed, was not personally critical of other historians who testified. ${ }^{228}$ Rousso's is a more superficial interpretation of the "guild" since it simply relates to decisions regarding testifying - his position does not discount a methodological guild. A more extreme but essentially similar debate arose following EEOC v Sears, Roebuck \& Co. ${ }^{229}$

Sears' expert was Professor Rosalind Rosenberg a women's history expert who testified that women were socialised not to seek risky employment such as existed with promoted posts. After the case, the Coordinating Committee of Women in the Historical Profession (CCWHP) passed a resolution stating that, as feminist scholars, they had responsibilities not to allow invocation of their scholarship contrary to the interests of women struggling against societal inequity. ${ }^{230}$ It noted that a number of women's history experts were asked to testify on Sears' behalf, but only one accepted and, consequently, that this respected scholar "buttressed Sears' defense against charges of sex discrimination". Ostensibly, this particular sub-guild was exercising "communal authority" and fettering academic freedom. ${ }^{231}$ While a pre-testimony censuring would be much more difficult to defend than a post-testimony procedure, arguably, academic freedom is irrelevant here. Rosenberg's academic publishing was unaffected. Rather, the resolution condemned the invocation of historical scholarship in the judicial lair, with all its profound implications. ${ }^{232}$ The resolution appears an extreme version of Rousso's position, threatening not the right to publish but to judicially disseminate research. It is not historians who should object to this resolution but lawyers.

Further, from a lawyer's perspective, given that experts use professional membership to boost their "expert-credibility", it seems entirely fair for professional associations to sanction members regarding irresponsible testimony. As was noted in Austin v American Association of Neurological Surgeons, such testimony harms the administration of civil justice because membership is used "to dazzle judges and juries and deflect the close and skeptical scrutiny that shoddy testimony deserves". 233 At the same time, an absence of guild-sanctioning should not, of itself, imply that testimony is responsible. The rare enforcement of ethical norms against testifying experts by professional associations suggests the invisibility of testimony to the respective guilds. ${ }^{234}$ Secondly, such guild-policing often relates to professions, like medicine, with explicit ethical codes. Beyond a baseline, that seems less the case with historians. Finally, and more worryingly, allowing professional review of members'

226 Fish, "Holocaust denial", n. 223 above, p. 524.

227 Spearing, "Don't go changing”, n. 225 above, pp. 325-34.

228 Rousso, The Haunting Past, n. 74 above, pp. 55, 58, 86.

229839 F2d 302 (7th Cir 1988).

230 K Jellison, "History in the courtroom: the Sears case in perspective" (1987) 9(4) Public Historian 9, p. 12.

231 Haskell and Levinson, “Academic freedom”, n. 161 above, p. 1630.

232 Farber, "Adjudication of things past", n. 179 above, p. 1015; Kessler-Harris, "Academic freedom”, n. 161 above, p. 430, Fink; "New historian", n. 9 above.

233253 F3d 967 (7th Cir 2001) 972.

234 Sanders, "Expert witness ethics”, n. 97 above, p. 1566. 
testimony risks the danger that the interests of the profession, not the public, are prioritised unjustifiably, thus restricting potential testimony particularly for plaintiffs. ${ }^{235}$

It is undeniably uncomfortable to witness guilds apparently invoking professional chills against those perceived to have uncovered ideologically inconvenient truths. ${ }^{236}$ However, the question of academic freedom only arises if ex-witnesses find it difficult to get published regardless of the methodologically sound, intellectually valuable, quality of their work. This would be unacceptable guild-wrath, potentially questioning the guild's authority. Such fears seemed unfounded in Irving. Irving had established historians testify for him without it spelling the end of academic careers, namely Sir John Keegan whose knighthood was for services to military history; and Professor Donald Cameron Watt, Emeritus Professor of International History at the London School of Economics. However, it should be acknowledged that both men had to be subpoenaed to ensure their appearances. Perhaps it might have been more self-imperilling for them to have given their evidence voluntarily.

\section{BAR-APPOINTED HISTORIANS}

Given the aforementioned difficulties, the appeal of a bar-appointed historian is strong as it appears to eliminate preconceptions of bias. In civil cases requiring specialist knowledge, European continental jurisdictions have traditionally used court-appointed experts. ${ }^{237}$ The trend is increasing in common law jurisdictions and is permissible in the US under rule 706 of the Federal Rules of Evidence. The NSW rules, previously mentioned, also make provision for court-appointed experts, ${ }^{238}$ specifying that courts can issue directions regarding issues to be dealt with in expert reports. Following the European Court of Human Rights, parties must be equally able to participate in a report's production (e.g. by submitting comments/documentation) ${ }^{239}$ and not only post-hoc. ${ }^{240}$ Bar-appointments could advise on admissibility and may appear instead of, or in addition to, adversarial experts. $^{241}$ However, under the NSW rules, if a court-appointed expert has been appointed, parties face difficulties in arguing for the admission of any other expert's evidence. ${ }^{242}$ Given the concerns regarding the institutionalisation or incorporation of experts into court processes, a legislative basis ensures that the expert-court relationship is defined in public not private law terms.

The bar-appointment initiative represents a shift away from oppositionalism and attendant presumptions that adversarialism's crucible produces more reliable conclusions. ${ }^{243}$ Inevitably, bar-appointment is resisted in gladiatorial US litigation as it wrests control from lawyers and challenges adversarialism, ${ }^{244}$ although there are some indicators of change. ${ }^{245}$ Historical bar-experts could still be cross-examined ${ }^{246}$ but, arguably, the advocates would be

235 P S Appelbaum, "Law and psychiatry: policing expert testimony: the role of professional organizations" (2002) 53 Psychiatric Services 389, p. 390.

236 Farber, "Adjudication of things past”, n. 179 above, pp. 1015, 1018.

237 Verkerk, "Comparative aspects", n. 219 above.

238 NSW rule 31.46.

239 Mantovanelli v France App. No 21497/93, paras 30 and 36.

240 Cottin v Belgium App. No 48386/99, para. 32.

241 Bernstein, “Expert witnesses”, n. 169 above, p. 478.

242 NSW rule 31.52, cf. SCR Part 39, rule 6.

243 Martin, "Historians at the gate", n. 32 above, pp. 1544-7.

244 Sanders, "Expert witness ethics", n. 97 above; p. 1581.

245 Verkerk, "Comparative aspects", n. 219, p. 184.

246 NSW rule 31.51; cf. SCR Part 39, rule 4. 
closer to historical method with experts "weigh[ing] the evidence and stand[ing] by interpretations even as they acknowledge the imprecision and revisability of their claims". ${ }^{247}$ Such a model also reinforces a favouring of professional validation (and some guarantee of faithfulness to methodological standards) over higher normative "truths".

In choosing experts, arbitration models could be followed whereby parties each choose one arbitrator, co-operating to choose a third. ${ }^{248}$ Presumably, for most issues, historical expertise is evident from membership of, principally though not exclusively, universities or professional associations such as the Royal Historical Society. Lists of experts could be compiled, although the creation of sacrosanct "thoroughbred stables" should be avoided. Further, the bar-appointment process should be transparent enough to ensure that experts are being engaged for their expertise rather than for the reflected glow of their hierarchically elite institutions, ${ }^{249}$ otherwise, a misplaced knowledge-aura might come into play. Finally, it is probably best to avoid resorting to private historical consulting enterprises who commercially depend on serving clients. Similarly, lawyers should not be nominees as they could slip in biased experts who would then appear with a misplaced burnish of neutrality. ${ }^{250}$ Some have suggested creating an obligation for lawyers to vet experts, but, leaving aside knowledge deficits, and difficulties regarding the consequences for failing such tests, ethical conundrums may arise as regards ensuring optimum representation for their clients. ${ }^{251}$ Rules which sanction lawyers for colluding in perjury will often be irrelevant as biased experts usually simply overstate or obfuscate.

At the moment, historians have discretion in acting as experts. Yet very few are registered with relevant expert witness bodies and perhaps such circumspection is understandable. However, should sufficiently qualified experts enjoy such discretion, especially in the scenario of bar-appointment? Some historians may wish to avoid appearing in conflict with their particular historical school of thought. Indeed, two prominent women's history experts refused to testify in Sears. ${ }^{252}$ Nevertheless, historians are not the most vulnerable witnesses and, in France, witnesses may not refuse to testify without the permission of the chief justice. ${ }^{253}$ Further, as has been noted, historical knowledge can be an indispensable factor in litigation. Mobile $\mathrm{v}$ Bolden concerned racial tensions accompanying the establishment of at-large voting districts in Mobile, Alabama. ${ }^{254}$ Few would have been impressed at historians refusing to testify due to the delicacies of historical truth. Such apparent preciousness would effectively debar any public discourse for historians. ${ }^{255}$ Surely historians can simultaneously defend what is unique and peculiar to history while accepting wider societal responsibilities as historians. ${ }^{256}$ That is surely true "total history". ${ }^{257}$ Further, despite pervasive nineteenth-century myths of historical disinterestedness, professional historians, as public servants and citizens "never escaped the burning questions of their age,

247 Martin, "Historians at the gate", n. 32 above, p. 1547, noting the favour for such an approach among historians, N E H Hull and P C Hoffer, "Historians and the impeachment imbroglio: in search of a serviceable history" (2000) 31 Rutgers LJ 473.

248 Martin, "Historians at the gate", n. 32 above, p. 1548.

249 Rousso, The Haunting Past, n. 74 above, pp. 46, 65.

250 Goodman, "Slipping through", n. 80 above, p. 865.

251 Sanders, "Expert witness ethics", n. 97 above, pp. 1562-4.

252 Jellison, "History in the courtroom", n. 230 above, p. 12.

253 Rousso, The Haunting Past, n. 74 above, p. 88.

254446 US 55 (1980).

255 Haskell and S Levinson, “Academic freedom”, n. 161 above, pp. 1657-8.

256 Mandler, “The responsibility”, n. 116 above, p. 22.

257 F Braudel, A History of Civilisations (London: Penguin 1993). 
either as participants or analysts". ${ }^{258}$ As one historical witness noted, perhaps the legal system can force historians "to crystallize our sense of purpose and the humanistic traditions that lend legitimacy to our field". ${ }^{259}$ Compelling expert witnesses depersonalises witnessing, perhaps removing post-litigation difficulties for those testifying.

\section{Conclusion}

Irving clearly contributed to the Holocaust's historical identity - how it is written about, described and represented as a historical event and Israelis in particular awaited the outcome with interest. ${ }^{260}$ In truth, negationists are despised due to their perceived miring in prejudice, the details of their arguments generally defy the liberal values of postHolocaust democracies. ${ }^{261}$ Indeed, British National Party personnel attended the Irving proceedings and the conclusion of the case coincided with the contemporaneous election victories of extreme right parties. It was in this context that Lipstadt assuredly maintained that the verdict was a "victory for all those who speak out against hate and prejudice", 262 and that Mr Justice Gray denounced Irving as a lying anti-Semite and racist.

Anthony Julius summed up Irving's importance thus: "It would have been important had we lost." 263 Two possible meanings might be drawn from Julius' statement. An Irving triumph might have installed him and his methodology in the credible historical academy. ${ }^{264}$ Alternatively, debates as to the Holocaust's existence might have been revived. This apparently challenges notions that the case used the historiographical approach rather than the historical one. It is important to avoid a "false complacency" 265 about Irving's lesson and to be clear about its limits. It did not re-stage the reality of the Holocaust and the door remains open to the methodologically sound Holocaust deniers, if they can exist. This may not please many of Irving's key actors. However, removing pre-ordained normative imbalances (as regards "factuality") deprives negationists of martyrdom. Instead, their indisputable shortcomings and inadequacies are examined and laid bare.

Irving condemned the judgment as "firstly, indescribable, and secondly, perverse". 266 He denied being anti-Semitic, maintaining that he had been victimised with the backing of Jewish leaders. ${ }^{267}$ While security staff hustled Irving out of court via a back exit, Lipstadt and her solicitors, along with Penguin's managing director, emerged through the front gates to greet the assembled press. Should successful defendants in cases debating evidence of atrocity offer triumphal sound-bites in bursts of camera flashes? Or, should they appear noble, unassuming, unaffected by victory's thrill? The latter sentiment derives much from the paradigm of liberation newsreels where silent images offer reproach. However, this would be to analogise inappropriately the court victory with the Holocaust itself and

258 Fink, "New historian", n. 9 above, p. 136.

259 Rosner, "Trials and tribulations", n. 83 above, p. 158.

260 Reeves, "State built on suffering", n. 136 above.

261 Spearing, "Don't go changing”, n. 225 above, p. 338.

262 A Buncombe, "A victory for all who speak out against prejudice”, The Independent, 12 April 2000.

263 Julius, "London and libel", n. 5 above, p. 9. See also J Libson and A Julius, "Losing was unthinkable. the rest is history", The Independent, 18 April 2000.

264 Burrell, "Rascist", n. 137 above.

265 Spearing, "Don't go changing”, n. 225 above, p. 324.

266 S Busfield, "Unrepentant Irving blasts 'perverse judgment”, The Guardian, 11 April 2000.

267 Ibid. 
Holocaust cases should not be theatricalised re-enactments of the past. ${ }^{268}$ Irving will not paralyse historical inquiry into this era, ${ }^{269}$ but it did highlight the difficulties in providing a legal context for the interpretation of historical evidence. This case was not really about tragedy but about evidence of misrepresentation - there is little of the heroic and nothing of the tragic about that. The judgment cannot resurrect the dead, but it does reinforce law's role in ensuring that the historical evidence of the lives and deaths of millions will not be misrepresented or distorted in court.

268 Rousso, The Haunting Past, n. 74 above, pp. 50, 56.

269 C Browning, "Historians and Holocaust denial in the courtroom" in J K Roth and E Maxwell (eds), Remembering for the Future vol. 1 (New York: Palgrave 2001), pp. 773-8. For more recent perspectives, see R Ashby Wilson, Writing History in International Criminal Trials (Cambridge: CUP 2011). 